\title{
Vagrant Voices: Summary, Citation, Authority
}

\author{
Janet Giltrow \\ University of British Columbia
}

\begin{abstract}
Describing student views of summary as anxious, and also incompatible with scholarly practice, this paper explores possibilities for addressing such views by developing theories of summary as citation. It begins by reviewing Teun van Dijk's "macrostructural" theory as a cognitive explanation for summary, and finds that, even with the addition of new-rhetorical genre theory to introduce social context to cognitive activities, a deficit persists in accounting for summary. Greg Myers' study of reported speech begins to speak to the deficit by showing conversationalists citing others to position themselves. Judith Butler's argument for linguistic agency is then called on to demonstrate the inherent instability in citation and the risk of change involved in all reiteration - these amounting to democratic "possibility." Mikhail Bakhtin's "revolutionary" philosophy of language then contributes perspectives on repetition of others' words which locate summary at the threshold of subjectivity. The paper concludes by describing summary as rendering positions in the social order, and attitudes towards summary as indications of ideologies of language itself.
\end{abstract}

Pour opposer une certaine vision étudiante du résumé, à la fois inquiétante et contraire aux pratiques du savoir, cet article se propose d'aborder le résumé du point de vue de la théorie de la citation. On passe, d'abord, en revue la théorie macrostructurale de Teun van Dijk qui consiste en une approche cognitive du résumé; même si cette théorie fait appel à une nouvelle rhétorique pour intégrer le contexte social aux activités cognitives, elle n'en demeure pas moins inadéquate pour rendre compte du résumé. L'étude du discours rapporté de Greg Meyer, pour sa part, relève davantage le défi du fait que les " conversationnistes » citent les autres pour se situer eux-mêmes. L'argument de Judith Butler sur l'agencement linguistique démontre, quant à lui, le caractère fragile de la citation et le danger de dérapage qu'implique la répétition, lesquels s'ajoutent à la liberté de choix. La conception révolutionnaire du langage de Mikhail Bakhtin, que l'on expose, apporte un autre éclairage 
sur la répétition des mots des autres en situant le résumé au seuil de la subjectivité. On conclut en décrivant le résumé comme un moyen de se positionner dans l'ordre social et d'envisager le langage lui-même.

Anne Carson's Autobiography of Red (1998) rewrites the story of Geryon and Herakles, recontextualizing the red monster and his assassin in times like ours. Inheriting her fable from the Greek poet Stesichoros, and posing a scholarly preface to the new version, Carson tells us that antiquity, even in efforts to preserve it, is a restless speech. Once disturbed by modern repetition, it will change, and, once roused, shift itself:

The whole corpus of the fragments of Stesichorus in the original Greek has been published thirteen times so far by different editors, beginning with Bergk in 1882. No edition is exactly the same as any other in its contents or its ordering of the contents. (6)

In our work to fix and perpetuate, we unwittingly (or cunningly) introduce variation; in seeking an official version, we introduce the insurgent.

$$
\star * *
$$

Writers of summary might be relieved of some of the embarrassments of composing-responsibilities for originality and invention, among others. Yet students seldom regard summary as care-free. Discussing summary with them, I ask, why do we summarize? How would you explain why we cite others' words and ideas? Often, even after weeks of study of scholarly genres, students still tell me that we summarize to "back up" our "own opinions." From this view, the free-lance statement unauthorized by a prior one is precarious and vulnerable. Further discussion of summary and citation - even after weeks of study of how research writers bring speakers together, arrange for and take a turn in their conversation-tends to uncover ideas about "plagiarism": we cite so as to avoid stealing ideas or words that belong to others. ${ }^{1}$ Operating in a high-risk zone, summary can secure an otherwise precarious position, but it can also expose that position to penalty. While I recognize these ideas of summary as widespread and durable, they don't quite fit my own: student writers appear to witness summary from a place near but not identical to mine. And in their summaries of scholarly publications, they can just miss the destination I have in mind for them. In their earlier efforts, they can look right past the writer's own citations, or miss the signs posting the writer's position, ${ }^{2}$ and even as they get used to summarizing, they can still have trouble accounting for the way the "original" itself summarizes other "originals," and belongs to a company of interlocutors. 
Thinking about ways to speak to students' concepts of summary, I realized that my own concept of summary was itself incomplete-not only in its inadequacy to address the perceptions of summary as the "backing-up" and "stealing" of ideas, but also in its inadequacy to account for aspects of my own experience: for example, the experience of reading summaries of my own writing - the feeling of looking in the mirror to see a stranger whom I resembled; or the experience of going ahead with my own earlier summaries of books or articles, and then returning to the originals to find that, while I had been away, they had changed! I began to re-think summary, hoping not only to understand better these various circumstances but also to understand their relation to one another. In this essay, I will consult a handful of theories for help in developing such understandings: Greg Myers' taxonomic study of reported speech in conversation; Judith Butler's account of citation and agency; Mikhail Bakhtin's observations on the traffic in wordings amongst speakers.

I approach these authorities having relied previously on two sources of ideas in my thinking about summary: (1) "macrostructural" theory of discourse comprehension; and (2) new-rhetorical genre theory.

\section{Macrostructural theory of discourse comprehension}

In language users' intuitions and capacities, Teun van Dijk's Macrostructures: An Interdisciplinary Study of Global Structures in Discourse, Interaction, and Cognition (1980) discovers evidence of levels of discourse: lower or "local" levels and higher or "global" levels, the latter being less detailed and more "relevant" (4). Language users mention "theme, topic, gist, or upshot"(5), and they are

able to make abstracts and summaries of discourses. Intuitively, such summaries are discourses that express the global meaning or main topics of the summarized discourse so that the summary relation between two discourses should also be formulated in terms of macrostructures. (10)

Van Dijk proposes, and van Dijk and Kintsch (1983) elaborate and apply, the idea of strategies-flexible, recursive, hypothesizing actions, steeped in complexity - to conceptualize language users' work in securing gist and producing summary, as well as in managing their reading experience for "storage" and "retrieval." For many years I have introduced students to practical versions of "levels" and "strategies" as moderately self-conscious reading/writing practices to apply to passages targeted for summary. I have few reservations about the effectiveness of these practices-as far as they go. 
But they only go so far. At the "macrostructural" stage in his long career as a theorist of language, van Dijk did keep in view "pragmatic macrostructures" (11) and "global functions" (6) as revealed in language users' intuitions and typified in questions like "'What are you doing?' "What are you driving at?"' ( 7 ), and recognized that

the derivation of macropropositions is very much socioculturally determined: Given certain acts and events, it definitely depends on social frames and cultural norms and values what we consider to be the global event or action now going on. (55)

Nevertheless, these ground-level considerations are overshadowed by the towering cognitive/semantic architecture of macrostructural theory. To notice this overshadowing is not to deny cognitive/semantic eminence but to seek additional perspectives.

Less easy to accommodate has been macrostructural theory's apprehension of words as stand-ins-stuntmen or fall-guys-for concepts.

... in this semantic formulation we are speaking about the existence of concepts and not of words of a natural language. It may be the case that higher-level concepts and macropropositions cannot be directly expressed in some natural language. (50)

This provision leaves untouched the materiality and sociality of language: its habits of collocation, its circulation amongst speakers, its infusion of interests and anticipation of rejoinders.

\section{$2 \mathrm{New}$-rhetorical genre theory}

In Strategies of Discourse Comprehension, van Dijk and Kintsch acknowledge "stylistic strategies," which can contribute to definitions of the social situation of the "discourse":

[A] language user will have ... the task of establishing some form of stylistic coherence, selecting or interpreting words from the same register and indicators of the same personal or social situation. For a listener, this means in particular the strategic use of stylistic markers to infer many proper- 
ties of the speaker or the social context, such as anger, love, compassion, dominance, or class membership, information that is vital for successful interaction. (17-18)

Complementary to stylistic strategies are "rhetorical strategies"-mainly "figures of speech"-which "enhance the effectiveness of the discourse and the communicative interaction" (18), providing pragmatic signals for the listener to recognize and structures for the listener to use in retrieving information. Van Dijk and Kintsch know that listeners must interpret speakers' intended "social action" (7), and "situational constraints," but specify that they will neglect situation (8) and "only occasionally take account of discourse types" (9). While it remains to be explored why a cognitive approach tends to cancel its own observations of language users' typifications of social motivations, and tends to reduce contextual factors to a list of Other Considerations, we can at least see that macrostructural theory leaves an unorganized space around the reader's/summarizer's encounter with the original.

New-rhetorical genre theory organizes this space by first recognizing discourse types as social action and as both recording motivation and informing it, ${ }^{3}$ and both representing and projecting recurring situations. Readers' and writers' activities then become sociocognitive (especially, Berkenkotter and Huckin 1995). Arranging and focussing on the discursive conditions which are only loose ends in cognitive models of summary, genre theory then permits us to concentrate on why readers and writers would employ discourse comprehension strategies; which readers and writers would employ discourse comprehension strategies; and how the strategies might differ amongst readers and writers according to their expectations and experience, and their roles in situations. Genre theory quizzes summary itself by requiring that it account for its own textual formation as an index of the situation it reckons: its readers' knowledge or ignorance of the original; and its properties as an entitled, stand-alone genre, as a contributor to a genre, or as a member of a cooperative group of genres. Genre theory asks about the genre of the original and the survival of this genre in the summary: does the summary name the originating genre, or reproduce it metonymically, by preserving certain stylistic features; or does the new situation annul the previous one? What are upshot and gist for? Study of the research genres suggests that summary can ratify (Swales 1991) the present writer, or invite (Geisler 1991) the writer to participate in a scholarly conversation, or negotiate (Berkenkotter and Huckin 1995) the terms of the writer's membership in the discourse community-functions which suggest the role of summary in positioning or identifying writers. Genre theory calls summary into question, usefully, and acclimatizes it. 
By taking a cognitive/semantic approach to summary and surrounding it with genre-theoretical explanations - and questions - students can get ready to write. Explicit "comprehension strategies" can turn reading into writing, and working contact with research genres puts writers in the midst of scholarly practices and motivations. Despite these conditions, however, I found amongst students a picture of summary which was different from mine, and I could not explain the difference. Summary has been the familiar foundation and friendly accomplice of my approach to teaching writing in the research genres, but I found it becoming unfamiliar. I began to reconsider summary: possibly the space between cognitive and social-action models was too big, and summary was wandering in it, lost?

Rather than work on filling in the space, and adding to the discipline's already large inventory of diagrams with intersecting sets, boxed subsets, and arrows routing readers and writers, I put aside both cognitive and genre conceptualizations (not discarding but reserving them) and began to experiment with reasoning which concentrates on summary as a type of reported speech and as instance of citation-as colloquy of consensus and opposition, copies, echoes, chimings in, reverberations - and, at the same time, a meta-linguistic occasion, when speech mentions speech.

Investigations of reported speech take many angles, but tend to settle around two stations of inquiry. Linguistic inquiry identifies syntactic and pragmatic features which distribute reported speech from Direct Speech to Free Indirect Speech, with forms of Indirect Speech in between. Literary inquiry goes after these forms in narrative, and takes a particular interest in Free Indirect Speech/Discourse (so, for example, Mezei (1996) explores the confounding ambiguity of Free Indirect Discourse). Between these stations, a growing number of studies looks at occurrences of reported speech in non-literary corpora. When in 1990 Patricia Mayes reported on quotation in spoken English, she could say that, while reported speech had "drawn the interest of researchers in several fields, including poetics, logic, philosophy, and the study of literature," it had not attracted much attention in linguistics, and the attention it had attracted either failed to account for function or failed to examine discourse samples $(325-26)$. But in the meantime, there have been many functional and linguistic, discourse-based studies of reported speech in writing - from studies of reporting in research genres (e.g., Hyland 1999) to news genres (e.g., Yelland's (2000) historical study of "speech and the idea of it" in a Chartist newspaper), and a smaller number have explored reported speech in conversation. Wallace Chafe (1994), for example, devotes considerable attention to reported speech amongst conversationalists in his search for the features of consciousness itself in language. In this middle ground, the linguistic and the literary meet, in a preoccupation with the social semiotics of reported speech. 
Here I focus on Greg Myers' recent suggestions (1999) for a taxonomy of functions of reported speech, derived from his analysis of $\mathbf{4 2}$ hours of discussion amongst participants in eight focus groups. Myers finds great complexity.

Speakers don't just tell about a past event that involves speech, but enter into a complex exchange, proposing and interpreting possible settings, marking factuality and counter-factuality, manoeuvring themselves and their interlocutors into positions, and focusing on the words themselves. $(380)$

Notably, in the 42 hours of discussion, Myers found no occasion where participants mistook reported utterance for the reporter's own (377)-despite the rarity of attributing expressions (396): "reported speech is used and recognized because of the way it does a job in interaction" (397). This suggests that the "jobs" performed by using the words of others are well known to language users: that reported speech is a means of expression second-nature to conversationalists, and, despite the complexity of uses, and the absence of overt signals, speakers and listeners manage these subtleties, undertones, and reservations. In some ways, conversationalists' reportings of the words of others are more complex than those in academic or technical and administrative summary. Like academic and technical summary, they are only "partial" (yet listeners know how to 'read' the part for the whole), but they can also be "hypothetical" - with no guarantee that anyone has actually said these things; rather, that they could be said, or that they should be said, or that they could not have been said (397). Listeners do not confuse hypothetical reports with actual ones, and do not begrudge speakers their concoction of these somehow realistic but unreal reports. The speaker vouches for the plausibility of the utterance in some possible world, and the listeners recognize this plausibility. Myers notes that hypotheticals are often called upon to position speakers and their listeners in contested situations:

Reports of hypothetical speech can be used to dramatize tensions. That may be why they so often involve voices of institutional authority, as in [an example where a focus group of unemployed men discusses residents' participation in maintaining council houses]: the apparently direct speech transforms the highly mediated and diffuse relations to authority into an ordinary encounter of individuals. Direct speech also allows the speaker to suggest a style for this imagined interaction.... (389) 
If we are not used to recognizing hypotheticals in summary, it's not because they are confined to speech, or erased by writing. Here, for example, the writer of a letter to a small-town newspaper reports a statement which in all likelihood has never been uttered, but which nevertheless realistically renders a dimension of social controversy:

Disincentives are everywhere for drivers [....] 'take transit so we can clog our arteries with fuel-hogging buses.'

I don't like it, and there is nothing I can do about it. (Letter to the editor, Tri-City News 2000 April 26)

This example supports Myers' speculations on hypotheticals as helping language users stake their own positions in powerful public discourses. Through this report, the writer temporarily controls a discursive atmosphere in which his own views have not got a hearing.

Hypotheticals help to organize not just a representation of the world, or a proposal for it, but also the alignments and affiliations of the participants--and so do other kinds of reported speech which Myers found in his corpus. Other voices can be summoned to represent a position around which participants gather in opposition, or one which rallies their solidarity. Reported speech can represent a position which, in anticipation of challenge, offers evidence for the speaker's own statement: a bit of speech can "prove" a characterization of a situation, or it can show that a proposition is strong enough to survive the immediate context-it's stated by others, outside. Reported Speech expands the discourse context to other settings, not only other speakers but also the shadow of the contexts in which they spoke-or "spoke."

In everyday speech, not only do participants have to manage such "shifts of frame" (378, Myers citing Goffman's term), but the shifts themselves are sites at which listeners must estimate the speaker's intention (positioned near or far? vouching for the words as actual, realistic, or only proposed? evidence for a contestable position or rallying point for consensus? consensus in agreement or opposition?). One clue as to how conversationalists manage these shifts comes from Myers' observation that reported speech appears only as parts of turns (rarely or never comprising the whole turn) and comes in "packaging" (380). Ventriloquating, impersonating, and authorizing, these mobile voices may accumulate such a dense record of movement- a network of traces, sightings, and sitings - that the speakers offer glimpses of their own subjectivity at each move. These partial glimpses congregate not to certainty and fixity but to a range of possibilities and trajectories.

In Myers' account, speakers invoke another context: the one attending the reported utterance. By detecting the original context, speakers are able to interpret the utterance as reported speech. Myers' analysis emphasizes these "shifts of frame." Judith 
Butler also sees the original context as attending the new one-the situation of the original speech shadows the situation in which the speech is repeated: prior occasions are always implicitly cited (1993: 220). But, in addition, the new context contends with the prior one. The work of Butler which I consult has as its general aim inquiry into the formation of the (hetero)sexualized subject and, in some of the writing I will cite, the more particular aim of inquiring into censorship, all housed in agreement with and dissent from Lacanian psychoanalytic theories of subject and language, and licensed by Derrida. While neither censorship nor sexuality pertain immediately to summary or reported speech, Butler's deliberations gesture towards matters which do pertain-matters of authority and control, and ownership of words and their occasions.

From Butler's discussion, we can derive overall principles: citation is unstable; repetition incurs risk of change. Why is this? How can it be that what seems to reproduce and indemnify an "original" in fact or effect jeopardizes the original?

An original statement acquires its authority from its imitators: if no copies follow, it is prior to nothing, and not an original. To this point, we see the authority of repeated/ cited/summarized statements as vulnerable to the motivations of speakers who follow it. It may be neglected, extinguished by silence, left to slumber undisturbed. (While summarizers may feel servitude to the original, the original is at the same time contingent on their initiative. Without the summarizer's service, the statement perishes, like a querulous or demanding invalid, bed-ridden.) But beyond this point, even if summarizers take up their pens, and cite-or repeat-the reproduction does not magically inherit the intentions of the original, or reinstate the context of the original. The original context and intention come into proximity-and contestwith the new ones. And "improper" intentions are possible: speech can be confiscated for purposes remote from its intentions. Advancing Derrida's notions of the illimitability of contexts, Butler says it is impossible to sustain mastery (1993: 227); the chain of citation is unpredictable (219); and the future will exceed control (228), for context can never be fully determined in advance (1997: 161). (At the same time, we might consider that the intentions-or re-invention of the intentions-of the original could return to assail the citation, for its incompleteness.)

Butler develops reasoning from Derrida's "Signature Event Context," in which he queries Austin on performatives, but Butler's review of performatives takes an angle slightly different from Derrida's. While Derrida criticizes convention as involving too many specificities to be adequate to fix future contexts for performatives, Butler focusses on the way (what is being called) convention cannot prevent an illegitimate or unlegitimated speaker from reciting an official wording (and crashing the party). Taking performative in a post-Austin sense, Butler sees a range of repeti- 
tion extending from the often-analysed performative of the magistrate pronouncing "husband and wife" to the "interpellation" (in this case "queer") which "echoes past interpellations, and binds the speakers as if they spoke in unison across time. In this sense, it is always an imaginary chorus that taunts 'queer!'" (1993: 226). It is a range of repetition extending from, that is, those sayings whose fidelity to an original is executed in ceremonial expectation and official monitoring to those whose repetition is located in tacit, shared understandings. But neither official monitoring nor shared expectations can prevent misappropriations.

In drawing this long reach of repetition, Butler inquires after instances which are "less explicit and juridical than the examples drawn from state power, i.e., marriage, declarations, pronouncements of various kinds" (1997: 153), but she also leaves a wide territory between these outposts of citation. In this territory, I suggest, occurs the range of repetitions which we recognize as summary: repetitions which are consciously accountable to the original but effective in rendering the social order precisely in the inexplicitness of their variation, as Myers' findings suggest. For Butler variation occurs not so much in wordings - for each of these poles is represented through exact repetition of words ("queer," "I pronounce you...")—but in context: identities of participant roles, scene, intention, relevance. Contexts can never be fully determined in advance, and neither can the dimension or motive of variation.

Butler pursues this reasoning to argue for "political promise" (1997: 144-45), to secure a future through break with the past (159). It seems that, for Butler, these promises are most visible as "insurrectionary" (144-45). But is there any reason to assign promise and futurities only to outlaws? The conditions she describes as permitting "democratic" expression are those which underlie everyday speech, including the speech which we anticipate or recognize as summary.

For Bakhtin, the chain of citation is not so traceable to an originary statement, not so much a chain (or lineage or patrimony) as an inundation: all utterances are "filled to overflowing with other people's words" (337); "of all words uttered in everyday life, no less than half belong to someone else" (339). But the circumstances of these citations are similarly variable, unpredictable in that each iteration encounters "new contexts," "new conditions," in attaching to the received wordings "new applications " $(345-46)$. This newness is most compellingly revealed in "novelistic privileges" (320). In the novel, the word arrives as already "bespoke," already "uttered" (331), reified and typical (possibly like the "hypotheticals" in use amongst Myers' conversationalists). The novelist forfeits originality but the word's typicality replenishes the vacated value of originality with the opportunity for artistic positioning vis-àvis the type: from solidarity with type, to rejection of it - and all the points in between, on an infinitely calibrated scale, a calculus of distance (298). These "privi- 
leges" particularly enrich the novelist, but they do not forsake the ordinary speaker. The "new contexts" for prior utterances are the domain of the everyday speaker: the opportunities, experiments, and incalculable possibilities are accessible from all speaking positions-"even in the narrowly scientific disciplines" (347). So, even as the "organic hybrid" (the everyday version of the intentional, artistic hybrid) is an "opaque mixing of languages" and therefore not identical to novelistic hybrids, ${ }^{4}$ it is nevertheless "profoundly productive historically": it is "pregnant with potential for new world views, with new 'internal forms' for perceiving the world in words" $(360)$. This is the promise of the future assigned by Butler, but unfolding in the interstices, reaccentuations, and impostures of everyday speech, not only the speech of activists or dissidents. Yet, while we can see divergence in the reasoning of Butler and Bakhtin, for opportunities are more widely distributed in Bakhtin's linguistic universe than in Butler's, their senses of possibility converge when they consider ideas of language itself.

Butler's arguments against censorship refer to a conceptualization of language: if we surrender the notion of the sovereign speaker, able to control and delimit future contexts, and we hazard unforeseen contexts, these democratic opportunities appear on the horizon. Linguistic agency is (paradoxically) discovered in the realization that "discourse has a history," and "this historicity effectively decenters the presentist view of the subject as the exclusive origin or owner of what is said" (1993: 227). In forfeiting copyright, the speaker also gets an option on other properties. And while she gets no guarantee that her own words will be saved harmless, she does get a right to enjoyment of the prospect of others' imposing words becoming themselves alienable, and in turn open to reformulations and reassociations in communities of possibility:

It is one of the ambivalent implications of the decentering of the subject to have one's writing be the site of a necessary and inevitable appropriation. But this yielding of ownership over what one writes has an important set of political corollaries, for the taking up, reforming, deforming of one's words does open up a difficult future terrain of community. (214-42)

Butler sees attempts to control, or "fully regulate" speech as both (a) impossible, for "mastery" is a fantasy and conceit (1997: 15); (b) destructive of "something fundamental about language" (27). The contexts and intentions of language cannot be guaranteed, but the idea that they can be controlled (the word and its use preserved) is itself injurious. 
Bakhtin too refers to an enabling philosophy of language: "a very important, in fact a radical revolution in the destinies of human discourse: the fundamental liberation of cultural - semantic and emotional - intentions from the hegemony of a single and unitary language, and consequently the simultaneous loss of a feeling for language as myth, that is, an absolute form of thought" (367). The revolutionary philosophy doesn't simply describe linguistic consciousness; it enables and transforms it-into a consciousness "organically participating in the universum of mutually illuminating languages... a fundamental intersecting of languages in a given consciousness, one that participates equally in several languages" (367-68). These philosophical activities un- "fetter" language from schemes of thought which "limit the world's potential for greater expressiveness" (369). This "revolution," however, is "possible only under very specific sociohistorical conditions" (367). So the social-semiotic play of citation and repetition, the play of summary itself, is measured by the surrounding ideologies of language, the prevailing ideas of what language is, these ideas in turn being in negotiation with social and political formations.

The ideology - or philosophy - of language which Bakhtin would overturn in order to revolutionize the re-speaking of others' words, claims a unitary, unconflicted language, abstract, mythically rendering the sacred fusion of the word and its single meaning. This unitary philosophy which Bakhtin attacks is an attempt at controlfor while it pictures the chastity of the word, it also attempts to prove that purity and inalienableness by warding off the indiscriminate, promiscuous forces which mix words, forces by which words surge and overwhelm strict intentions. The unitary philosophy of language also develops a model of the speaking subject as one who directly expresses his or her own meaning and intention, and no other. This speaker is franchised by poetics, and poetry is idealized as personal, sovereign, owned by the speaker. Whether or not we regard poetry as the auxiliary of unitary views of language (and Bakhtin had his own reasons for unmasking poetry, just as Butler has hers for arguing with censorship), we could speculate that the ideal of the "owned" voice is foundational to an ideology of language which also confers authority on the other voice: the official one, or the dictatorial one, the imposing one. Student writers coached to regard utterances as inalienable and sovereign-hungry for control, and capable of it too - may regard their repetitions of others' words as obedience rather than possibility. The idea of property rights to one's own voice has as its reciprocal the propriety of the original which is summarized (an original which can turn angry if it is betrayed, or absconded with).

Remote as some of Bakhtin's deliberations may be from the classroom summary or the technical or administrative one, his view includes such episodes. 
When verbal disciplines are taught in school, two basic modes are recognized for the appropriation and transmission-simultaneously-of another's words (a text, a rule, a model): "reciting by heart" and "retelling in one's own words." The latter mode poses on a small scale the task implicit in all prose stylistics: retelling a text in one's own words is to a certain extent a double-voiced narration of another's words, for indeed "one's own words" must not completely dilute the quality that makes another's words unique; a retelling in one's own words should have a mixed character, able when necessary to reproduce the style and expressions of the transmitted text. It is this second mode used in schools for transmitting another's discourse, "retelling in one's own words," that includes within it an entire series of forms for the appropriation while transmitting of another's words, depending upon the character of the text being appropriated and the pedagogical environment in which it is understood and evaluated. (341-42)

This account provides for, at once, the survival of the other's words (and intentions?), and their "appropriation" by the new speaker, in a responsible but inexplicit "mix." The account also opens immediately onto Bakhtin's further discussion of the "individual's ideological becoming" (342) - the train of discussion presenting summary as contiguous with the threshold of subjectivity. The subject materializes by incorporating into consciousness - and reproducing in utterance-wordings ranging from externally "authoritative discourse" to "internally persuasive discourse." The externally authoritative is sealed; in artistic contexts it is "a dead quotation" (344), like the "evangelical texts in Tolstoy at the end of Resurrection" (344), a remote "official line" more or less "distanced from the zone of contact" (344) according to the rhetorical coordinates of the occasion. But the internally persuasive word "is, as it is affirmed through assimilation, tightly interwoven with 'one's own words' " (345) and acknowledges others' words as others'. It is this speaking subject then who acts/utters-to "develop, apply" the hybrid word to "new material, new conditions," to "[enter it] into interanimating relationships" (345-46). On the particular occasion of summary, all this range from mute submission to active incorporation is possible.

From these discussions, we can capture a sense of citation as a means of positioning - an articulation of subjectivity. For Butler, the insurrectionary subject evades mastery and declares itself in the very act of repetition, a commando raid on headquarters. For Bakhtin, things aren't so incendiary, but they are still politically de- 
clarative: the repetition of others' words is a moment for calculating the speaker's distance from or proximity to another subjectivity-an occasion for positioning. Myers' research shows that Bakhtin's "revolutionary" philosophy of language accurately predicts the range of positions and possibilities broached by reported speech: the roving voices of the focus-group participants at each move can signal an identification or a disavowal, a venture to the cited position, a retraction or invention. Student writers' anxieties about citation - the insecurity of one's "own opinion," the immanent penalty for appropriation-suggest that they may experience summary as only one move, to the cited position, from which they disappear unless tracked down by the law and charged with plagiarism. Along similar lines, I have found students reluctant to entertain or respect evidence I offer them about scholars happily reading summaries of articles or books they themselves have already read: these people, I claim, are reading for the summarizer's position, and attending to it as performing one of the many "jobs" of reported speech-producing a rallying point for consensus or dissent, affiliation or ratification; developing a concern for the speech act itself. For students, a more convincing account is that summarizers are seeking "back-up," and expecting to have their credentials checked.

The hypotheticals which Myers discovered' are especially good at showing us that, in the democratic speech imagined by both Butler and Bakhtin, it's a position in the social order that is invoked by reported speech-a complex of interests and attitudes, and institutional formations, reconfigured for populist aims. But the democracy of reported speech in conversation does not seem to survive the transfer to classroom summary - unless, perhaps, it were to be accompanied by a revolutionary ideology of language. If summary goes on, instead, under a regime with ambitions for control-universal prescriptions for usage, reverence for the official voice, penalty for transgression, enforced property rights over the word-then possibilities for newness reduce to the slim chance of contradiction: "Giltrow says such-and-such and I disagree." The implicit philosophy of language at work amongst focus-group participants is cheeky, lawless, promiscuous, and opportunistic. But western traditions, both formal and public, of thinking about language have tended to quench such undisciplined yet practical techniques.

Students' ideas of summary are indices of the ideological atmosphere which surrounds language education and institutional uses of language. While any language practice might provide such indices, summary may be a particularly fertile field of indications, for summary is itself a meta-linguistic gesture: it is speech about speech, and its performance involves rumours of the whereabouts of meaning. Moreover, as study of Myers, Butler, and Bakhtin has revealed (to me), one of the outstanding issues (for me) in theorizing summary is the vagrancy of meaning: what is the plane 
of repetition? Is it the word or the context which is seeking perpetuity? Since summaries are shorter than originals, some words will be sacrificed. Does their forfeiture mean that the context-intention and action-of the original is the main thing (being the "spirit" of the original)? And the point of anxiety? For the word is capable of exact repetition, while the context is not. And the survival of the word can risk the intention: if a scholarly statement, for example, is cited word-for-word in a non-scholarly context-in written reasons for judgement or report of a commission of inquiry, in a feature article or, some might say, in a student essay-the statement, notoriously, loses its grip on the earlier speaker's scholarly intentions. Yet words are themselves invested with motives, attitudes, and interests of their prior contexts: Myers' conversationalists could detect shifts of frame, hearkenings to another context, even without the overt signals of reporting expressions.

Is summary about the survival of the word, or the survival of the context? Is the greatest tension around the perishing (or dictating) word-or the perishing (or imposing) context? Will different originating genres, or different destination genres, locate these tensions differently? Would student summarizers imagine themselves differently-and compose differently - if they were schooled in a revolutionary philosophy of language, one which recognized the instability of citation, and replaced notions of originality and authority with ideas about position subjectivity?

\section{Notes}

${ }^{1}$ A study of the circumstances of first-year writing (Cooke and Derksen 1999) revealed that, among students at five university colleges in British Columbia, "plagiarism" was a gripping concern: $87 \%$ of respondents to a questionnaire identified "an understanding of plagiarism and how to avoid it" as an "essential" writing proficiency. Plagiarism was the top choice among 20 proficiencies (next - with $78 \%$ of students identifying it as "essential"-was "ability to write coherent paragraphs").

${ }^{2}$ So, again and again, students have summarized this passage for me-

Because their formative period was relatively recent, the 17 th and 18th centuries, [creole languages] are often seen as not yet fully formed complex languages. The descriptions of creole languages in some linguistic circles are similar to the attitudes of many creole speakers toward their languages. These languages are described as "reduced," simple, and easy 
to learn; lacking in abstract terms, they are inadequate for scientific, philosophical, and logical operations. For most of their histories, creole languages have not been considered adequate for government, schooling or Western religious services (Schieffelin \& Doucet 1994).

- as something like this: "Because they are recent and not fully formed, creole languages are too simple to be used for scientific, educational, or governmental purposes," or "Schieffelin and Doucet note that creole languages, because they have developed relatively recently, are too simple to be used for ..." etc.

${ }^{3}$ Carolyn Miller $(1994,1984)$, in the landmark publication to which genre theorists customarily refer, observes that "what we learn when we learn a genre is not just a pattern of forms or even a method of achieving our own ends. We learn, more importantly, what ends we may have..." (38).

${ }^{4}$ In the novelistic hybrid, two voices are dialogically engaged in the same unit of utterance.

s Anticipating Myers' discovery, Mayes (1990) also found that direct speech, while generally regarded as more exact or reliable than indirect, was not exact: in her sample, "half the direct quotations [were] not authentic renditions, and many [were] inventions of the speaker" (358).

\section{Works Cited}

Bakhtin, M. M. (1981). The Dialogic Imagination, trans. C. Emerson and M. Holquist. Austin: $U$ of Texas Press.

Berkenkotter, C., \& Huckin, T. (1995). Genre knowledge in disciplinary communication: Cognition/Culture/Power. Hillsdale NJ: Erlbaum.

Butler, J. (1997). Excitable speech: A politics of the performative. New York: Routledge. (1991). Bodies that matter. London: Routledge. 
Carson, A. (1999,1998). Autobiography of Red: A novel in verse. Toronto: Vintage Canada.

Chafe, W. (1994) Discourse, consciousness, and time: The flow and displacement of conscious experience in speaking and writing. $U$ of Chicago Press.

Cooke, V., \& Derksen, R. (1999). Review of the proficiencies required by students entering first year post-secondary English courses. Ministry of Education, Centre for Curriculum, Transfer and Technology.

Derrida, J. (1988, 1977). Signature event context. In Limited Inc., ed. G. Graff, trans. S. Webber \& J. Mehlman. Evanston: Northwestern UP.

van Dijk, T. A. (1980). Macrostructures: An interdisciplinary study of global structures in discourse, interaction, and cognition. Hillsdale, NJ: Erlbaum.

van Dijk, T. A., \& Kintsch, W. (1983). Strategies of discourse comprehension. New York: Academic Press.

Geisler, C. (1991). Toward a sociocognitive model of literacy: Constructing mental models in a philosophy conversation. In C. Bazerman \& J. Paradis (Eds. ), Textual dynamics of the professions. Madison: $U$ of Wisconsin Press.

Hyland, K. (1999). Academic attribution: Citation and the construction of disciplinary knowledge. Applied Linguistics, 2o( 3), 341-367.

Mayes, P. (1990). Quotation in spoken English. Studies in Language, 14(2), 325-363.

Mezei, K. (1996). Who is speaking here? Free indirect discourse, gender, and authority in Emma, Howards End, and Mrs. Dalloway. In K. Mezei (Ed.), Ambiguous discourse: Feminist narratology and British women writers. Chapel Hill: U of North Carolina Press.

Miller, C. (1994, 1984). Genre as social action. In A. Freedman \& P. Medway (Eds.), Genre and the new rhetoric. London: Taylor and Francis.

Myers, G. (1999). Functions of reported speech in group discussions. Applied Linguistics, 20( 3), 376-401.

Swales, J. (1991). Genre analysis: English in academic and research settings. Cambridge UP.

Yelland, C. (2000). Speech and writing in the Northern Star. Labour History Review, 65(1), 22-40. 